\title{
The Effect of Pre-Class Assignment in Enhancing the Chinese National-Type School Pupils in Mastery Chinese Language
}

\author{
Ke Bing Ling, Fong Peng Chew*
}

Department of Language \& Literacy Education, University of Malaya, Kuala Lumpur, MALAYSIA

*Corresponding Contact:

Email: fpchew@um.edu.my

Manuscript Received: 30 Dec 2020

Accepted: 24 Sept 2021

\begin{abstract}
The KSSR curriculum system introduced by Malaysia's ministry of education is demanding teachers to build pupils who will have the ability to carry out the learning process independently. To build pupils with the ability to learn independently, the pre-class assignment is an implementation needed to give the learning autonomy back to pupils. However, some of the teachers do not like students to do any pre-class assignment because they are afraid that students who have already obtained a certain level of understanding towards the learning materials would feel boring and show the signs of being not interested to listen during the in-class learning process. Thus, this study aims to study the effect of pre-class assignments in enhancing the Chinese language reading comprehension mastery level of pupils from Chinese national-type schools in order to convince more educators to start practicing the use of preclass assignments. A group of 260 pupils from eight different schools in Kuala Lumpur was involved in this study. A quantitative approach was used in this study and tests were developed and used in this study. The result of this study showed that the implementation of pre-class assignments was effective in helping pupils to master Chinese language reading comprehension. The finding of this research showed that the pupils' performance in Chinese language reading comprehension was not affected by the language used at home and prior exposure of pupils towards pre-class assignments.
\end{abstract}

Keywords: Pre-class assignment, Chinese language reading comprehension, Languages used at home, Prior exposure to pre-class assignment

This article is is licensed under a Creative Commons Attribution-NonCommercial 4.0 International License.

Attribution-NonCommercial (CC BY-NC) license lets others remix, tweak, and build upon work non-commercially, and

although the new works must also acknowledge \& be non-commercial.

\section{INTRODUCTION}

According to Ibrahim et al. (2011), the Malaysian multiracial society can be illustrated through the existence of the three main ethnics namely Chinese, Malays, and Indians. As children born in Malaysia, the Malaysian young citizens are always taken as having the ability and being competent in using various types of languages in their daily 
communication by giving meaning to those different types of languages used. However, the truth is the multilingual environment of Malaysia has caused Malaysians, especially children to experience difficulties in practicing all the languages learned fluently.

\section{Statement of Problem}

In the 21st century which is a century that is filled with various kinds of information, our country is changing our curriculum system to ensure Malaysian students are not being left behind. In conjunction with the curriculum changes, our ministry of education had introduced the Standard Curriculum Primary School (KSSR) that listed all the characteristics of students that our new curriculum system aimed to implement in students. One of the characteristics that Malaysian students should have is the curiosity towards knowledge. To produce learners with the ability to carry out the learning process with their effort, pre-class assignments should be given to students before their classes, giving them the chance to carry out the reading activities, subsequently generate thoughts about the reading materials, and relating the information obtained through those assignments with syllabuses taught before. Pre-class assignments promote pupils' before class preparations by designing activities that encourage the learners to watch videos, carry out thinking activities related to their learning materials and complete the exercises given by teachers independently (Huang et al., 2014). Critical thinking and self-learning are encouraged when learners are working to complete the pre-class assignments. Meanwhile, teachers' role and responsibilities in the teaching and learning process is reduced from being the source of knowledge to more of an advisor.

However, there are still many teachers who are being resistant to changes as they are not being paid more or given any rewards even when they are committing their own time and money to work extra in the process of adapting the curriculum changes introduced by the country (Sulaiman et al., 2015). Besides, Wu (2017) stated that some of the teachers do not like students to do any pre-class assignment because they are afraid that students who have already obtained a certain level of understanding towards the learning materials would feel boring and show the signs of being not interested to listen during the in-class learning process. Due to the teachers' resistance towards changes, the effort to change the teaching approach from a teacher-centered approach to a student-centered approach is having a hard time to be made possible in Malaysia. According to Yunus and Arshad (2015), the 'spoon-feeding' teaching approach in Malaysia has caused the Malaysian learners to have strong dependence toward their teachers, causing them to be incapable to think independently and critically resulting in low creativity, inhibiting their real potential and self-confidence. Due to the unwillingness of the teachers in Malaysia to abandon the teacher-centered approach, the implementation of pre-class assignments to would enable learners to learn independently is facing a lot of problems and difficulties to take place in Malaysia.

According to Ettekal and Mahoney (2017), the ecological system theory had acknowledged the effect of the various types of the environment surrounding an individual towards the individual's academic achievement. As many researchers around the world have researched and proved that there are so many factors that will give an effect on the academic achievement of a particular learner, some educators who were being resistant to the implementation of preclass assignment might claim that the improvement in learners' reading comprehension performance was due to other affecting factors instead. Hence, the pre-class assignments are still not widely used in Malaysia even after being proved to be effective in improving learners' reading comprehension performance in other countries and contexts. 
In conclusion, there are still many problems in the educational field in Malaysia that is discouraging the improvement of the learners' reading comprehension performance. Besides, the implementation of pre-class assignments as a solution for improving learners' reading comprehension performance has been facing hardship to be carried out successfully in Malaysia. Hence, research about the importance of the pre-class assignment that includes all the background factors affecting the reading comprehension performance of the learners is very important to make Malaysia educators realize the essentiality of the pre-class assignments and even encourages the further researchers about it. Therefore, this study aims to study the below research questions:

- What is the pupils' mastery level in Chinese language comprehension?

- Is there any significant difference between the pupils in Chinese national-type schools with prior exposure to pre-class assignments and without?

- Is there a significant difference in pre-class assignment test performance between the pupils of the different languages used at home?

\section{Methodology}

The research methodology applied in this study is a survey which involved test in the process of collecting information. The researcher used the quantitative to identify the effects of the pre-class assignments in helping the Chinese-medium school pupils in improving their mastery in the Chinese language.

\section{Population and Respondents of the Study}

The year four pupils are the group of pupils that just entered the upper primary and are facing problems in understanding the long text in the textbook. Hence, the year four pupils from Chinese national-type schools are being chosen as the respondents of the study by the researcher.

Table 1 shows the population distribution of the study by listing out the number of pupils in each school.

Table 1: Population of the Study

\begin{tabular}{|c|c|c|c|}
\hline Zone & School & Number of pupils in year four & Number of respondent \\
\hline Bangsar & A1 & 150 & 26 \\
& A2 & 210 & 36 \\
& A3 & 340 & 43 \\
& A4 & 150 & 25 \\
\hline \multirow{3}{*}{ Pudu } & B1 & 210 & 30 \\
& B2 & 240 & 33 \\
& B3 & 340 & 33 \\
& B4 & 360 & 34 \\
\hline & Total & 2000 & 260 \\
\hline
\end{tabular}

Bangsar and Pudu were chosen because they are the zone with the most number of schools. School in the Bangsar zone has already implemented the pre-class assignments for years. However, the pupils in the Pudu zone did not receive the implementation within their four years of primary school life. Therefore, the researcher chose four schools from the Bangsar and Pudu zone to be the sample of the research. All of the four schools chosen are a school with similar results, pupils' family background, and learning environment. After that, the researcher applied random sampling methods to choose respondents from each school. 


\section{Instruments of Study}

The type of instrument used in the study was the test. In the research, a test was being conducted by the researcher after the pupils complete the in-class learning session for each of the chapters. The test was conducted to determine the mastery of the pupils toward the text in the textbook after having a pre-class assignment before learning. The test contained five objective questions and five subjective questions. All the questions were designed to measure the comprehension performance of the pupils. The tests given by the researcher to the pupils were validated by the lecturer in teachers' training college and trained Standard Curricular trainer of Kuala Lumpur.

In this study, the researcher conducted a pilot test on a group of 40 pupils to examine the internal consistency of the instrument designed. Singh (2017) describes internal consistency as an aspect of reliability related to the consistency of the questions, which enables the researcher to gather similar feedback from similar questions.

The outcome of the pilot test was being analyzed. Based on Vegada et al. (2014), tests' reliability coefficient $(r)$ was categorized: Magnificent $(0.9 \leq r)$, Exceptional $(0.8-0.9)$, Acceptable $(0.7-0.8)$, Poor $(0.6-0.7)$, Required amendment $(0.5-0.6)$ and Problematic $(0.5>$ r). The researcher obtains a reliability coefficient of 0.82 through the pilot test and based on the reading stated by Vegada et al. (2014), a reliability coefficient of 0.82 is within the exceptional range, proving the high reliability of the test.

\section{Profile of Respondents}

Table 2 showed the distribution of the respondents in the research based on gender and language used at home. The 260 pupils were built up from 130 male pupils and 130 female pupils. Based on table 2, there is more than half of the respondents $(67.3 \%)$ use the Chinese language at home. The English language is the language with the second higher using rate for home language, occupied $28.5 \%$ of the respondents. The least language used by pupils was others, which only have $4.2 \%$ of the respondents. Since the research was conducted in the Chinese national-type school, it is reasonable for the majority of the respondents to have the Chinese language as the main language used at home.

Table 2: Respondents' Demographic Information

\begin{tabular}{|l|l|c|c|c|}
\hline $\begin{array}{c}\text { Respondents' } \\
\text { Profile }\end{array}$ & \multicolumn{1}{|c|}{ Category } & $\begin{array}{c}\text { Bangsar Zone (\%) } \\
\mathbf{n = 1 2 9}\end{array}$ & $\begin{array}{c}\text { Pudu Zone (\%) } \\
\mathbf{n = 1 5 5}\end{array}$ & $\begin{array}{c}\boldsymbol{\Sigma} \mathbf{( \% )} \\
\mathbf{N}=\mathbf{2 8 4}\end{array}$ \\
\hline Gender & Male & $65(25)$ & $65(25)$ & $130(50)$ \\
& Female & $65(25)$ & $65(25)$ & $130(50)$ \\
\hline Language Used at & Chinese & $79(30.4)$ & $96(36.9)$ & $175(67.3)$ \\
Home & English & $42(16.2)$ & $32(12.3)$ & $74(28.5)$ \\
& Other & $9(3.5)$ & $2(0.8)$ & $114.2)$ \\
\hline
\end{tabular}

\section{FINDINGS}

\section{Research Question 1}

What is the pupils' mastery level in Chinese language comprehension?

The mastery level of the pupils in the Chinese Language that were focused on the reading comprehension were being divided into four categories, which are "Targets", "Advanced", "Proficient", "Basic" and "Below Basic". The target of the researcher is for pupils to achieve all 7 objective questions and all 3 subjective questions correctly $(9 \%-10 \%)$. The 
"Advanced" mastery level referred to pupils that can achieve 5 to 6 objective questions and 2 subjective questions correctly $(7 \%-8 \%)$. Besides, the "Proficient" level is being referred to pupils that achieved 4 to 5 objective questions and 1 subjective question correctly ( $5 \%$ $6 \%$ ). "Basic" referred to pupils that answered 3 to 4 objective questions and 0 subjective questions correctly (3\% - 4\%). Lastly, "Below Basic" referred to pupils that answered 0 to 1 objective questions and none of the subjective questions correctly $(0 \%-2 \%)$.

After every text comprehension class, the respondents were given one comprehension test. Hence, the respondents in this research had sat for a total of three tests. Table 3 showed the Chinese language mastery level of the respondents.

Table 3: Respondents' Chinese language Mastery Level

\begin{tabular}{|c|c|c|c|c|c|}
\hline Zone & Level & $\begin{array}{c}\text { Mark } \\
\text { Range (\%) }\end{array}$ & $\begin{array}{c}\text { Test } 1 \\
\text { Frequency } \\
(\%)\end{array}$ & $\begin{array}{c}\text { Test } 2 \\
\text { Frequency } \\
(\%)\end{array}$ & $\begin{array}{c}\text { Test } 3 \\
\text { Frequency } \\
\text { (\%) }\end{array}$ \\
\hline \multirow{5}{*}{$\begin{array}{l}\text { Bangsar }(\%) \\
n=130\end{array}$} & Target & $9-10$ & $2(1.6)$ & $11(8.5)$ & $49(37.7)$ \\
\hline & Advanced & $7-8$ & $28(21.5)$ & $41(31.5)$ & $43(33.1)$ \\
\hline & Proficient & $5-6$ & 45 (34.6) & $39(30.0)$ & $22(16.9)$ \\
\hline & Basic & $3-4$ & $40(30.8)$ & $32(24.6)$ & $11(8.5)$ \\
\hline & Below Basic & $0-2$ & 15 (11.5) & $7(5.4)$ & $5(3.8)$ \\
\hline \multirow{5}{*}{$\begin{array}{l}\text { Pudu (\%) } \\
n=130\end{array}$} & Target & $9-10$ & $14(10.8)$ & $16(12.3)$ & $40(30.8)$ \\
\hline & Advanced & $7-8$ & $30(23.0)$ & $41(31.5)$ & $45(34.6)$ \\
\hline & Proficient & $5-6$ & $39(30.0)$ & $40(30.8)$ & $34(26.2)$ \\
\hline & Basic & $3-4$ & $27(20.8)$ & $22(16.9)$ & $9(6.9)$ \\
\hline & Below Basic & $0-2$ & 20(15.4) & $11(8.5)$ & $2(1.5)$ \\
\hline \multirow{5}{*}{$\begin{array}{l}\Sigma(\%) \\
N=260\end{array}$} & Target & $9-10$ & $16(6.1)$ & $27(10.4)$ & $89(34.2)$ \\
\hline & Advanced & $7-8$ & $58(22.3)$ & $82(31.5)$ & $88(33.9)$ \\
\hline & Proficient & $5-6$ & $84(32.3)$ & $79(30.4)$ & $56(21.5)$ \\
\hline & Basic & $3-4$ & $67(25.8)$ & $54(20.8)$ & $20(7.7)$ \\
\hline & Below Basic & $0-2$ & 35 (13.5) & $18(6.9)$ & $7(2.7)$ \\
\hline
\end{tabular}

Pupils in Bangsar zone are the pupils who had been very familiar with the pre-class assignment as pre-class assignments are the common assignment given to them before comprehension class in normal learning activities.

Based on Table 3, the frequency of the pupils who scored the "Target" level increased from only $2(1.6 \%)$ pupils in Test 1 to $11(8.5 \%)$ pupils in Test 2 and ended with a high frequency of $49(37.7 \%)$ pupils achieving "Target" level in Test 3. Besides, the number of pupils who achieved the Chinese language mastery level of "Advanced" has also experienced some increase since the first test. In Test 1, there were 30 (23.0\%) pupils obtain "Advanced". The number of pupils who achieved the "Advanced" level increased to 41 (31.5\%) in Test 2 and the number of pupils who obtained this level increased to $43(33.1 \%)$ at the end of the research. These two highest mastery levels in the Chinese language had both experienced increases throughout the research.

The pupils in the Pudu zone experienced the same situation. There were only 14 (10.8\%) pupils achieved the "Target" level in the first test. However, there were $40(30.8 \%)$ pupils managed to achieve the "Target" level at the end of the research. "Advanced" level in the Pudu zone experienced the same increase too. In Test 1, there were only 30 (23.1\%) pupils who achieved "Advanced". At the end of the research, the number of pupils achieved the "Advanced" level increased to 45 (34.6\%) pupils. 


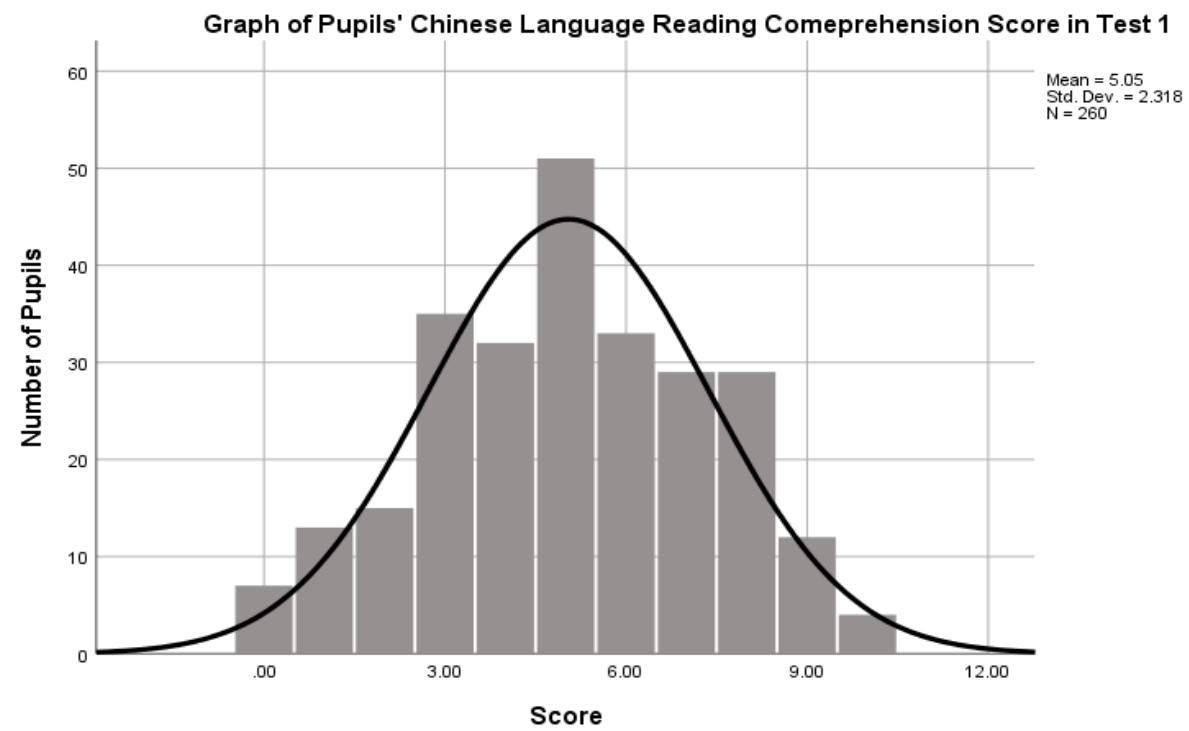

Figure 1: Histogram of Pupils' Reading Comprehension Performance in Test 1

To answer the research question about the mastery level of pupils' Chinese language comprehension the researcher produced a histogram. Based on the histogram, the distributions of the score of the 260 respondents are roughly symmetric. The scores with the most scorers in test 1 was 5 marks. Besides, most pupils score around 5 marks making most scores fall in the middle of the distribution. Among the 260 respondents in the research, the highest score of the respondents was 10 marks and the lowest score of the respondents was 0 marks.

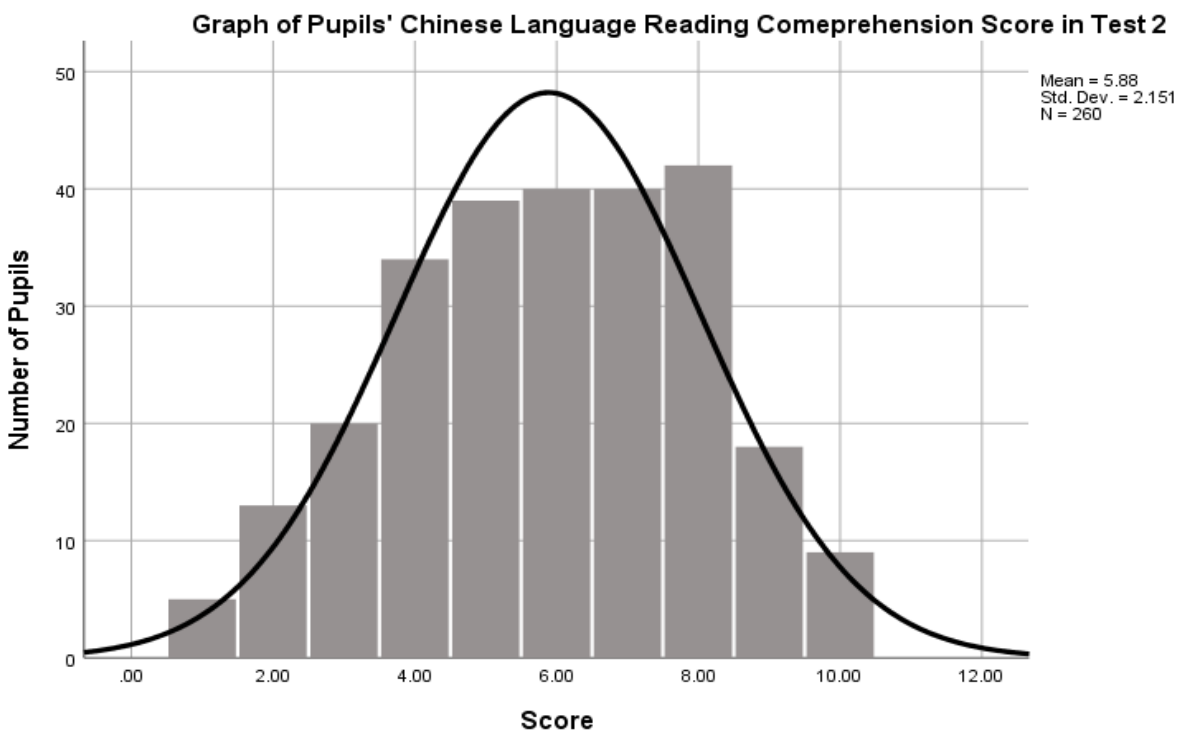

Figure 2: Histogram of Pupils' Reading Comprehension Performance in Test 2

According to Figure 2, the distribution of the score of the 260 respondents in test 2 was still roughly symmetric. In test 2 , the score with the most scorers were 8 . The average score of 
the 260 respondents improved to 6 marks in test 2 but most of the scores still fall in the middle of the distribution. In test 2, the lowest score of the respondents improve to 1 and the maximum score of the respondents remain as 10 .

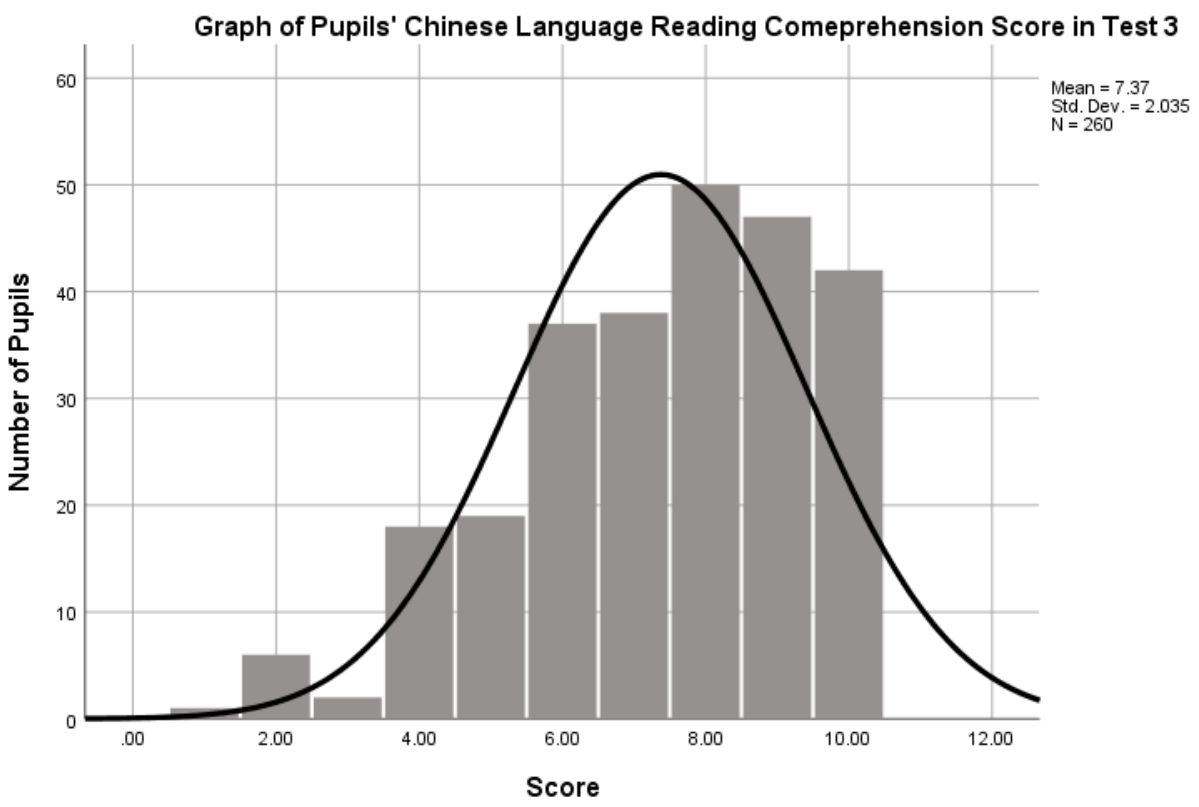

Figure 3: Histogram of Pupils' Reading Comprehension Performance in Test 3

Based on Figure 3, the distribution of the score of the 260 respondents in test 3changed and became slightly skewed to the left or negatively skewed. The score with the most scorers in test 3 remains as 8 . However, the average score of the respondents improves to 7 marks, making most of the scores fall at the right side of the distribution. In test 3 , the lowest score of the respondents remain as 1 and the maximum score of the respondents remain as 10 .

According to the mean score of the respondents in the research, the mastery level of the pupils in Chinese language comprehension has improved from Proficient level in test 1 (5\%) and test $2(6 \%)$ to Advanced level $(7 \%)$ in test 3 . In conclusion, the mastery level of the pupils in Chinese language comprehension has improved throughout the research.

Table 4: Chinese Language Reading Comprehension Mastery of the Pupils

\begin{tabular}{|l|c|c|c|c|c|c|}
\hline \multirow{2}{*}{} & \multicolumn{2}{|c|}{ Test 1 (10\%) } & \multicolumn{2}{c|}{ Test 2 (10\%) } & \multicolumn{2}{c|}{ Test 3 (10\%) } \\
\cline { 2 - 7 } & Bangsar & Pudu & Bangsar & Pudu & Bangsar & Pudu \\
\hline Mean & 4.87 & 5.22 & 5.80 & 5.97 & 7.45 & 7.29 \\
\hline Standard Deviation & 2.05 & 2.55 & 2.09 & 2.22 & 2.14 & 1.93 \\
\hline Minimum & .00 & 0.00 & 1.00 & 1.00 & 1.00 & 2.00 \\
\hline Maximum & 10.00 & 10.00 & 10.00 & 10.00 & 10.00 & 10.00 \\
\hline
\end{tabular}

Besides, the researcher had analyzed the Chinese language reading comprehension mastery of the pupils using percentage, mean and standard deviation to answer the research question of identifying the difference between the pupils in Chinese national-type schools with the implementation of pre-class assignment and without. The researcher had produced Table 4 to compare the performance of the respondents from Bangsar and Pudu zone in the three tests that were carried out throughout the research. 
The mean, standard deviation, minimum value, and maximum value of the respondents' Chinese language reading comprehension mastery were presented in Table 4 . In the first test, the pupils in the Pudu zone that were newly introduced to pre-class assignments have better performance $(\mathrm{M}=5.22, \mathrm{SD}=2.55)$ compare to pupils in the Bangsar zone $(\mathrm{M}=$ 4.87, $\mathrm{SD}=2.05)$. The pupils in the Pudu zone continued to perform better $(\mathrm{M}=5.97, \mathrm{SD}=2.22)$ than pupils in the Bangsar zone $(\mathrm{M}=5.80, \mathrm{SD}=2.09)$ in the second test. However, the pupils in the Bangsar zone managed to score better $(\mathrm{M}=7.45, \mathrm{SD}=2.14)$ than pupils in the Pudu zone $(\mathrm{M}=7.29, \mathrm{SD}=1.93)$ in the last test.

\section{Research Question 2}

Is there any significant difference between the pupils in Chinese national-type schools with prior exposure of pre-class assignments and without?

To answer the research question, the researcher had conducted an independent-sample t-test at an alpha level of .05. The result of the independent-sample t-test is shown in Table 5.

Table 5: Independent-Sample T-Test of Pupils' Chinese Language Mastery Level between Locations

\begin{tabular}{|c|c|c|c|c|c|c|c|c|c|c|c|c|c|c|c|}
\hline & \multicolumn{5}{|c|}{ Test 1} & \multicolumn{5}{|c|}{ Test 2} & \multicolumn{5}{|c|}{ Test 3} \\
\hline Area & $\mathrm{N}$ & M & SD & $\mathrm{t}$-value & $p$ & $\mathrm{~N}$ & M & SD & $\mathrm{t}$-value & p & $\mathrm{N}$ & M & SD & $\mathrm{t}$-value & $\mathrm{P}$ \\
\hline Bangsar & 130 & 4.9 & 2.1 & -1.232 & & 130 & 5.8 & 2.1 & -0.634 & & 130 & 7.5 & 2.1 & & \\
\hline Pudu & 130 & 5.2 & 2.5 & & 0.219 & 130 & 6.0 & 2.2 & & 0.527 & 130 & 7.3 & 1.9 & 0.639 & $0.5<3$ \\
\hline
\end{tabular}

According to Table 5, the results of the independent-sample t-test performed showed that in test one $(t=-1.232, p=0.219)$, test two $(t=-0.634, p=0.527)$ and test three $(t=0.639, p=0.523)$, $p>0.001$ is greater than the significance level $\alpha=0.05$ that was chosen by the researcher. Thus, the researcher accepts the null hypothesis that "there is no significant difference between the pupils in Chinese national-Type School with prior exposure of pre-class assignment and without".

\section{Research Question 3}

Is there a significant difference in post-pre-class assignment test performance between the pupils of the different languages used at home?

The researcher performed an independent t-test to answer research question five. The result of the independent t-test was shown in Table 6.

Table 6: Independent-Sample T-Test of Pupils' Chinese Language Mastery Level between different Languages used at Home

\begin{tabular}{|c|c|c|c|c|c|c|c|c|c|c|c|c|c|c|c|}
\hline & \multicolumn{5}{|c|}{ Test 1} & \multicolumn{5}{|c|}{ Test 2} & \multicolumn{5}{|c|}{ Test 3} \\
\hline Language & $\mathrm{N}$ & $\mathrm{M}$ & SD & $\mathrm{t}$-value & $\mathrm{p}$ & $\mathrm{N}$ & M & SD & $\mathrm{t}$-value & $\mathrm{p}$ & $\mathrm{N}$ & $\mathrm{M}$ & SD & $\mathrm{t}$-value & $\mathrm{P}$ \\
\hline Chinese & 175 & 5.2 & 2.4 & & & 175 & 6.0 & 2.2 & & & 175 & 7.4 & 2.1 & & \\
\hline $\begin{array}{c}\text { English } \\
\text { and other } \\
\text { languages }\end{array}$ & 85 & 4.7 & 2.2 & 1.540 & 0.123 & 85 & 5.7 & 2.1 & 0.893 & 0.373 & 85 & 7.3 & 2.1 & 0.560 & 0.576 \\
\hline
\end{tabular}

According to result shown in Table 6, the independent-sample t-test performed showed that in test one $(t=1.540, p=0.123)$, test two $(t=0.893, p=0.373)$ and test three $(t=0.56, p=0.576), p>0.001$ is greater than the significance level $\alpha=0.05$ that was chosen by the researcher. Thus, the researcher accepted null hypothesis two that "there was no significant difference in post-pre-class assignment test performance between the pupils of the different language used at home". 


\section{DiscuSSION AND RECOMMENDATIONS}

The pupils' Chinese language reading comprehension mastery level has experienced improvement throughout the process of the research. The improvement of the 260 respondents from Bangsar and Pudu zone can be seen clearly through the mean score scored by the pupils. This research has proved that pre-class assignment has a positive effect in helping learners to have better mastery level in Chinese language reading comprehension. This finding of the research was consistent with the findings of various past studies (Azizifar et al., 2015; Haque, 2010; Gouia and Gunn, 2016; Stang et al., 2016; Kuo, 2016; Kung, 2016; Miller et al., 2018; Jensen et al., 2018) in proving pre-class assignment was a useful implementation that helped learners to get more out of the learning process.

According to Schema Theory (Carell, 1984), prior knowledge is very important in making text meaningful and making it possible for learners to have a deeper comprehension level towards the text. Michaelsen et al. (2002) stated that when learners are completing the preclass assignments, they were taking the responsibility to learn and develop a lower level of cognition. Hence by completing the pre-class assignment, learners will be able to comprehend a particular text better as they take their existing knowledge along during the comprehension process (Adam and Collin, 1977; Langer, 1984). However, the reading comprehension mastery level of pupils in both Bangsar and Pudu zone in test one, test two and test three did not show a significant difference. This result indicates that the pupils' reading comprehension mastery level is not affected by the prior exposure of the learners towards pre-class assignments.

In conjunction with the result of the research, previous pre-class assignment researches that involved long term implementation (He, 2016; Stang et al., 2016; Kung, 2016; Kuo, 2016; Miller et al., 2018) and short term implementation (Leonard et al., 2012; Azizifar et al., 2015; Haque, 2010; Gouia and Gunn, 2016) of pre-class assignment on learners with no prior exposure to pre-class assignment all showed a positive result. Hence, the pre-class assignment is strongly proven to have no relation with whether the learners have prior exposure to pre-class assignments or not. Among the 260 respondents in this research, there was a different language used at home. However, the result of this study shows that there were no significant differences in Chinese language reading comprehension mastery level between pupils with different languages used at home. The finding of this research is in line with the multicultural context in Malaysia. In 2015, China Press (November 17, 2015) reported a year six Malay pupil has achieved a good performance of 6A1B in UPSR. Besides, Oriental Daily (December 19, 2016) also reported about Malay twin sisters from Alor Star who also proved their high Chinese language mastery level by scoring A in their PT3 exam. These news reports have proved that language used at home is not the reason for pupils to be unable to have high Chinese language mastery level.

These cases are strongly supported by Suryantari (2018) it is commonly believed that children have a better performance when it comes to second language learning because these young learners can learn a second language more easily and in a shorter time. Hence, as long as the Chinese reading comprehension mastery level of the pupils in Chinese national-type schools are given more attention, the pupils will be able to have a good mastery level without influence by the different language used at home.

According to Seman et al. (2017), the performance of Malaysian learners in higher-order thinking skills (HOTS) is very weak. As reading comprehension is an activity that requires learners to have the critical thinking, reasoning, creative thinking, and innovation, 
educators need to start developing the learners' thinking skills through improving the learners' reading comprehension performance. Based on the finding of the research, the pre-class assignments are proven to be able to help in improving the learners' reading comprehension performance. Hence, the researcher strongly suggests the pre-class assignments to be implemented in all of the primary schools in Malaysia.

There were numbers of educators in Malaysia who were being resistant towards the implementation of the pre-class assignment as they were worried that learners would feel boring during the in-class learning process after they obtained a certain level of understanding towards the learning materials through pre-class assignments $(\mathrm{Wu}, 2017)$. However, it was proven by the finding of the research that the pre-class assignments will not cause the pupils to feel bored about the learning materials. Oppositely, it was proved that pupils were able to have a better level of understanding of the passage after they completed the pre-class assignments. Hence, the result of the research conducted showed that there was no reason for the pre-class assignments to be not implemented in the reading class.

According to Derakhshan and Karimi (2015), different languages used at home by learners did harm second language learning. However, the finding in this research had proved that learners with different languages used at home will have the ability to have a higher Chinese language reading comprehension mastery level as long as the pre-class assignments are implemented. Thus, having different languages used at home should not be the reason for pupils to not learn the Chinese language or even not studying in a Chinese national-type school. The result of this research has brightened up the learning of Chinese language for pupils with different home languages as it was proven through this research that the pupils will be able to master Chinese language reading comprehension well as long as they were learning with the help of the pre-class assignments.

In Skinner's (1953) theory of behaviorism, positive reinforcement is relying on the rule that the rapidity of a certain response or actions rises as it was given stimulus with positive rewards. In conjunction, the desired behavior will then increase because of the positive reward followed by it (Budiman, 2017). Generally, pupils love having a special status as the person who is having the best performance in the class with a special reward that all the other pupils do not have the chance to enjoy. Hence, verbal compliments, special homework exception, little gifts were used as stimulus in this research has shown good effect as all the 260 respondents completed all the pre-class assignments given.

Skinner's theory of behaviorism (1953) emphasizes the use of positive reinforcement that would enable the pupils to complete the task given. Based on the result of this research, even when some of the pupils responded that their perception towards pre-class assignment was not all positive, they still completed all the pre-class assignments assigned by the researcher as positive reinforcement will be given if they do so. Hence, the blending of Skinner's theory of behaviorism (1953) with pre-class assignment in Malaysia Chinese national-type school context was proven to be effective through this research.

Besides Skinner's theory of behaviorism (1958), the implementation of the pre-class assignment was conducted using Carrell's schema theory (1984) as a guideline. Carrell and Eisterhold (1983) had stated that a text will not bring any meaning by itself but the readers will have to carry forward their previous schemata from their memory to make sense out of the text. Hence, the schema theory is a theory that highlights that prior knowledge is very important in making the text meaningful and making it possible for the readers to have a deeper comprehension of the text read. 
In this research, the pre-class assignment acted as the instrument that helped the 260 pupils in Chinese national-type schools to build their prior knowledge. Pre-class assignments including pre-class video, pre-class reading, and pre-class reading guides were assigned to pupils. These assignments helped the pupils to build the linguistic schema, content schema, and formal schema that acted as the connecting bridge to enable pupils to comprehend the text better. Based on the finding of the research, the pre-class assignments have a positive effect on helping pupils in Chinese national-type schools to build useful schema and caused them to have higher Chinese language reading comprehension mastery levels. Thus, pre-class assignment as an instrument to build schema based on the schema theory (Carrell, 1984) was proven to be effective in the Chinese national-type school in the Malaysian context. In conclusion, this research has proved that the implementation of pre-class assignments using Carrell's schema theory with the support of Skinner's theory of behaviorism (1953) was effective in helping pupils in Malaysia Chinese national-type school context to have a higher level of mastery level in Chinese language reading comprehension.

\section{ConcLusion}

As a conclusion, the implementation of pre-class assignments was effective in helping pupils to master Chinese language reading comprehension. Besides that, the positive effect of the pre-class assignments was not affected by whether the pupils had prior exposure towards the use of pre-class assignments. In addition, the positive effect of the pre-class assignment was not affected by the type of languages used at home by the pupils. Therefore, the pre-class assignment should be implemented to help pupils in mastering Chinese language reading comprehension.

\section{REFERENCE}

Azizifar, A., Roshani, S., Gowhary, H., \& Jamalinesari, A. (2015). The Effect of Pre-reading Activities on the Reading Comprehension Performance of Ilami High School Students. Procedia - Social and Behavioral Sciences, 192(June 2015), 188-194. https:/ / doi.org/10.1016/j.sbspro.2015.06.027

Budiman, A. (2017). Behaviorism in Foreign Language Teaching. English Franca, 1(02), 101-114.

Carrell, P. L. (1984). Schema Theory and esl Reading: Classroom Implications and Applications. The Modern Language Journal, 68(4), 332-343. https://doi.org/10.1111/j.1540-4781.1984.tb02509.x

Carrell, P. L., \& Eisterhold, J. C. (1983). Schema Theory and ESL Reading Pedagogy. Tesol Quarterly, 17(4), 553-573. https://doi.org/10.2307/3586613

China Press. (2015, November 17). 巫裔华小生考获6A1B 父亲: 欣喜、欣慰. Retrieved from https://www.chinapress.com.my/20151117/巫裔華小生考獲6a1b-父親：欣喜、欣慰/

Derakhshan, A., \& Karimi, E. (2015). The Interference of First Language and Second Language Acquisition. Theory and Practice in Language Studies, 5(10), 2112. https://doi.org/10.17507/tpls.0510.19

Ettekal, A., \& Mahoney, J. (2017). Ecological Systems Theory. In K. Peppler (Ed.), The SAGE Encyclopedia of Out-of-School Learning (pp. 239-241). https://doi.org/10.4135/9781483385198.n94

Gouia, R., \& Gunn, C. (2016). Making mathematics meaningful for freshmen students: investigating students' preferences of pre-class videos. Research and Practice in Technology Enhanced Learning, 11(1). https:// doi.org/10.1186/s41039-015-0026-9

Haque, M. M. (2010). Do Pre-reading Activities Help Learners Comprehend a Text Better? BRAC University.

He, W. (2016). Investigation of the Effects of Flipped Instruction on Student Exam Performance, Motivation and Perceptions (University of California, Irvine). https://doi.org/10.2337/diacare.22.5.762 
Huang, Y., Liu, J., Yin, P., \& Chen, L. (2014). “翻转课堂”教学模式设计的几点思考*. 现代教育技术， 24(12), 100-106. https://doi.org/10.3969/j.issn.1009-8097.2014.12.0015

Ibrahim, R., Muslim, N., \&Buang, A. H. (2011). Multiculturalism and higher education in Malaysia. Procedia - Social and Behavioral Sciences, 15, 1003-1009. https://doi.org/10.1016/j.sbspro.2011.03.229

Jensen, J. L., Holt, E. A., Sowards, J. B., Ogden, T. H., \& West, R. E. (2018). Investigating Strategies for Pre-Class Content Learning in a Flipped Classroom. Journal of Science Education and Technology, 27(6), 523-535. https://doi.org/10.1007/s10956-018-9740-6

Kung, L.-C. (2016). 以预习阅读提升学生数学学习成效之行动研究. 台北市立大学.

Kuo, F.-H. (2016). The effects on the "Reading Comprehension Strategies Preview- worksheet" for Fourth graders' reading ability and attitude. 国立新竹教育大学.

Langer, J. A. (1984). Examining Background Knowledge and Text Comprehension. Reading Research Quarterly, 19(4), 468-481. https://doi.org/10.2307/747918

Leonard, S. N., Murphy, K., Zaeem, M., \&DiVall, M. V. (2012). An introductory review module for an anti-infectives therapeutics course. American Journal of Pharmaceutical Education, 76(7), 3-8. https://doi.org/10.5688/ajpe767135

Michaelsen, L. K., Knight, A. B., \& Fink, L. D. (2002). Team-Based Learning: A Transformative Use of Small Groups. Westport, CT: Praeger Publisher.

Miller, K., Lukoff, B., King, G., \& Mazur, E. (2018). Use of a Social Annotation Platform for Pre-Class Reading Assignments in a Flipped Introductory Physics Class. Frontiers in Education, 3(March), 1-12. https:// doi.org/10.3389/feduc.2018.00008

Ministry of Education. (2015). Dokumen Standard KurikulumPentaksiran Bahasa Cina. Putrajaya: Bahagian Pembangunan Kurikulum.

Oriental Daily. (2016, December 19). 吉 华 巫 裔 双 胞 胎 11A. Retrieved from https://www.orientaldaily.com.my/news/nation/2016/12/19/176575

Seman, S. C., Yusoff, W. M. W., \& Embong, R. (2017). Teachers Challenges in Teaching and Learning for Higher Order Thinking Skills (HOTS) in Primary School. International Journal of Asian Social Science, 7(7), 534-545. https://doi.org/10.18488/journal.1.2017.77.534.545

Skinner, B. F. (1953). Science and Human Behavior. United States of America: The Free Press, A Division of Simon \& Schuster Inc.

Skinner, B. F. (1958). Reinforcement today. American Psychologist, 13(3), 94-99. https://doi.org/10.1037/h0049039

Stang, J. B., Barker, M., Perez, S., Ives, J., \& Roll, I. (2016). Active learning in pre-class assignments: Exploring the use of interactive simulations to enhance reading assignments. Physic Education Research Conference 2016, (July), 332-335. https://doi.org/10.1119/perc.2016.pr.078

Sulaiman, T., Ayub, A. F. M., \& Sulaiman, S. (2015). Curriculum change in English language curriculum advocates higher order thinking skills and standards-based assessments in Malaysian primary schools. Mediterranean Journal of Social Sciences, 6(2), 494-500. https://doi.org/10.5901/mjss.2015.v6n2p494

Suryantari, H. (2018). Children and Adults in Second-Language Learning. Tell : Teaching of English Language and Literature Journal, 6(1), 30. https://doi.org/10.30651/tell.v6i1.2081

Vegada, B. N., Karelia, B. N., \& Pillai, A. (2014). Reliability of four-response type multiple choice questions of pharmacology summative tests of II M.B.B.S students. International Journal of Mathematics and Statistics Invention (IJMSI), 2(1), 6-10.

Wu, C. H. (2017). 论小学语文学习中学生预习的重要性. Education Modernization, 8(35), 325-327. https://doi.org/10.16541/j.cnki.2095-8420.2017.35.133

Yunus, M. M., \& Arshad, N. D. M. (2015). ESL teachers' perceptions toward the practices and prospects of autonomous language learning. Asian Social Science, 11(2), 41-51. https://doi.org/10.5539/ass.v11n2p41 